\title{
Health Seeking Behaviour by Cape-Townians: a 'mini-research by first year student nurses at a College for Nursing in Cape Town
}

\author{
S Haegert
}

\begin{abstract}
The author was asked by a student nurse to use South African examples when teaching, as the text books were either American or English, and they wanted sociology that applied to their own environment. In the next year of teaching the prescribed objectives concerning "Health Seeking Behaviour", it was suggested that the students question the populace, and find out for themselves how South Africans behaved when they thought they were ill. By doing this it was hoped that it would also give deeper insights into the meaning people attributed to illness/sickness.
\end{abstract}

\section{Opsomming}

Die skrywer was deur student verpleegkundiges gevra om Suid-Afrikaanse byvoorbeelde te gebruik wanneer sy Sosiologie onderrig, want alle teksboeke was of Amerikaans of Engels, en studente wou iets he wat toepaslik by hul eie omgewing is. Tydens die volgende jaar se onderrig van "Health Seeking Behaviour", het die skryfster die klas gevra om hul eie navorsing te onderneem. Die artikel beskryf hul ondervindinge en wys aan dat dit 'n werklike metode is om studente te help leer van hul eie land, mense, en 'n nuwe vak. Sodoende was dit gehoop dat studente 'n grooter insig sou behaal oor die betekenis wat mense aan hul sieke toepas.

\section{Introduction:}

In the first year of teaching Sociology at Carinus Nursing College I was asked by nurses to use South African examples as the text books were either American or English and they wanted sociology that applied to their own environment. In the next year of teaching the prescribed objectives concerning: "Health Seeking Behaviour" I suggested that they go out, question the populace, and find out how South Africans behaved when they were ill.
By doing this it was hoped that it would also give deeper insights into the meaning people attributed to illness/sickness. Another reason for doing this was that this module fell in the student's last block after their written examinations, and teaching new material was no easy task.

\section{Purpose of the Study:}

de Jong (1987) discusses, under health care from a medical-anthropological viewpoint, the health-seeking behaviour of Guinea-Bissau African folk. He describes what he sees as the different health care sections in that country: the popular, folk and professional care sectors. He adds that there are three functions of any health care system: the first - to give meaning to suffering; the second -healing per se; and the third communication during the healing process.

Whether one accepts that Africans have migrated South or not, it was felt that it would be relevant to use de Jong's Guinea-Bissau work to give this study an academic framework. If one quotes from Leininger (1981), Leininger \& Watson(1990), Mashaba \& Brink (1994), McGee(1994), Spector (1991), Masi et. al. (1993), or de Villiers \& van der Wal (1995) the message is that one should be more culturally aware. And, not only of our patients or clients as we go into Primary Health Care, but of our student nurses for they too have rich cultural diversity to be explored.

The Question: The study centres on giving meaning to suffering; taking suffering in its widest sense and asking: "What meaning do sick persons attribute to their illness"? It is felt that the answer to this question would ultimately affect the other two functions especially from a cultural point of view.

\section{Methodology:}

Basically this was a qualitative study at a very elementary level. Students were given a week to ask five people, whom they could choose. three questions. The questions posed to people were:

1. How do you know that you are sick;

2. What do you do when you are sick; and,

3. What do you think causes you to be sick?
A total of 74 (five male- and 68 female-) students took part in this project ${ }^{1}$. This gave an interviewee population of 365 persons ${ }^{2}$. These persons were of the usual ethnic groups of the Cape: Xhosa, Caucasian, Indian and Coloured. Although the majority of the interviewees were female (number identified $=166$ ), there was also a representative male group ( 79 males). Ages ranged from 6 to $70+$ years. They were variously employed from scholars (2), students (not only nurses), housewives, accountant, boat builder, teachers, doctors, professional nurses, storeman, pensioners. A full list was not given as not all nurses mentioned employment.

One must remember that these were first year $\mathrm{R} 425^{3}$ student nurses engaged in their second module of Sociology. They had no previous research experience. Research as a main subject features in their fourth year. They were instructed about research from the point of view of using the structured questions and writing down verbatim what the interviewees said in response to them. They had to identify themes, similarities and dissimilarities, and make a summary or conclusion. The results would count as their test (continuous assessment) mark. Some students did well, even going beyond their five interviewees. some asked less than five. Some students gave no demographic details (age, gender, race, employment); some gave ethnic grouping only, some gender only. Marks ranged from $30-80 \%$. 288 respondents could be categorised as given in Table 1 (79\% of total number interviewed).

Analysis: Individual students sorted their questions into categories i.e. either each person and the three answers; or, each question and their interviewees' answers. It was then a matter of creating a demographic grid, and sorting into themes. The question of categorizing into ethnic groupings is controversial. If all groups were totally 'westemized' there would be no problem, but also nothing of interest. However the results

sec Tabk 1

2 As will be seen from the statistical table $L$ not all students gave the necessary demographic data so although this number was interviewed they were unable to be categorised as 10 gender. ethnic group or age.

3 Diploma in Nursing. Psychiary, Community Nursing and Midwifer 
TABLE 1: to show (Ethnic Groupings \&) Number of Interviewees interviewed by FIRST YEAR (1995) STUDENTS

\begin{tabular}{|l|r|r|r|r|r|}
\hline Interviewers & $\begin{array}{c}\text { TOTAL } \\
\text { Student }\end{array}$ & Indian & White & Coloured & Black \\
\hline Indian & 2 & 2 & 2 & 3 & 2 \\
White & 15 & 1 & 46 & 11 & 8 \\
Coloured & 36 & 3 & 12 & 120 & 18 \\
Black & 21 & 2 & 6 & 8 & 43 \\
TOTALS & 74 & 8 & 66 & 142 & 71 \\
\hline
\end{tabular}

show trends applicable to specific cultural groups, and the health care sectors mentioned by de Jong. For that reason alone the results were classified.

Comments: At the time of this study there was absenteeism from a 'flu epidemic amongst the students. Those students who became interviewees (19 nurses) reflect this in their identifying symptoms, analysing diet, taking vitamins, and feeling exceptionally stressed.

As students undertook this 'research' in their own time and amongst peers, family, neighbours, friends, and the local public no formal proposal nor official permissions were sought.

Even with the given limitations the results reveal the health-seeking behaviour of the interviewed population. Having realised this, I informed the students that I felt their work had academic value and that I would attempt to have it published. The work is theirs, my contribution is giving it an academic framework and typing it. My reason is to show 1) that sociology can be learnt in this innovative manner; 2) that given the right directions students can be involved in research from early in their training; 3 ) that whatsoever material is obtained in this way could be utilized in other subjects e.g. community health, health promotion, ethics, etc., and 4) that the data has socio-cultural value and enabled them to learn that sociology can be fun!

Results: Will be given as per question, highlighting themes, many of which were repeated to saturation point and others merely one-offs.

Question 1: "How do you know that you are sick?" (see Table 2a).

'Westernised' people look for symptoms. The commonest reaction was: "when my body feels different" (and some added: "from yesterday, or my normal self'). Two doctors compared how they had felt the previous day. Many "listened to what their body was saying". Non-westernised Africans went by dreams or experiences (see Table 3) feeling something moving in/or eating that part of the body that was thought to be sick e.g. in their stomach, or back. One interviewer concluded: "Nobody can tell anybody that they are sick.
Its very personal. Some people say they are sick when they have a common cold, others don't take it as sickness. They are in their own ways responsible for their health".

Question 2. What do you do when you are sick? (see Table 2b).

It was surprising how many Western/ized people took panados or grand-pa powders and med-lemon tablets together in the initial stages of their illness. A large number commented that unless one belonged to a medical aid it was too expensive to visit a doctor. Therefore they treated themselves. Either they obtained something from the chemist or they took their own familiar 'home remedies ${ }^{4}$. Those who belonged to medical aid said they would go to their doctors in the first instance, especially if a certificate was necessary. Others felt that because they belonged to medical aid they could rush to the doctor at the slightest disease.

Nurses divided their interviewees into categories. One coloured nurse commented, "There is a belief amongst older persons in traditional Hollandse or patent medicines". Another called them "raatjies". One wrote: "The coloured race resorts to westernised medicine." "Cultural beliefs play an important role in the management of illness by an individual". People from traditional African culture said that they would "slaughter an animal", "make beer", visit a diviner (a sangoma), "ask the elders for a second opinion", "have a family 'come together'", use 'herbs' or 'muthi', and "ask the ancestor for protection". In one instance it was said that "the Sangoma would cut a little hole in my body and put in some mud (like immunisation) to prevent demons (tokoloshe) from doing harm". Others would go to the herbalist (or Inyanga). How people view their health has implications for health care providers and its consumers. As question 3 indicates it sets the pattern regarding the subsequent action that consumers will take. I believe that this could be researched further with great profit.

Question 3: "What do you think causes you to be sick?" (see Table 2c)

\footnotetext{
4 herbal remedies: borstal, herbs, traditional medicine chemist/self-mediation: panados, vicks, med. kemon, camphor, cough-syrup vitamins: cal-c-vita and berocca c.
}

This question uncovered cultural diversities, and confirmed that people want to make sense of illness or disease. One interviewer wrote: "I've asked black people from my street. Most of them are Christian meaning that they don't believe in the traditional way of healing, neither do they believe in witchcraft."

Some interviewees came from rural areas. There was talk of "bad spirits", "forefathers", of "ancestors (who had) stopped protecting me", "witchcraft poison", and "umthakathi". This is in line with de Jong (1987:44) "When somebody feels sick, he will try to find out what (or who) is bothering him. To answer this question is the first function of a health care system, i.e. to give meaning to suffering or illness in order to engender the healing practice". "The sufferer's judgement rather than that of biomedicine defines the underlying problem" (op. cit. 45).

One nurse commented: "It's a loss of harmony in the body". And from a homeless man: "I just go around asking for a tot of liquor or asking for money to buy panado. I am sure it is not getting any liquor at all because when I'm finished with drinking the pain goes".

And again, "Younger people felt that getting sick was more self-inflicted e.g. alcohol, drugs, not being dressed warmly, change of seasons, allergies ... whereas older people acknowledged that it is more stress-related loneliness and depression". This question revealed that people do seek meaning for their illness/sickness and that it affects their perception in terms of healing (see Table III)

\section{Conclusions and Recommendations}

Oosthuizen (1996:193) says in dealing with cultural differences ethically: Nurses "should be able to explain why it is necessary to develop cultural awareness". Many nurses interviewed respondents from their own ethnic culture and furnished cultural and ethical recommendations that they felt came out of their work, and, which could be taken further when reseach is studied in the final year. Add to this the student's own insights and some very interesting sociological observations came forth confirming the African literature; interesting cultural patterns for other ethnic groups also came to light. This project had other benefits:

1. It gave students a taste for research. Many said how they had enjoyed doing it. They wished they could do more as they learnt so much about people and their health-seeking behaviour while they were doing it. It made the text-book discussion on this topic more 'alive'.

2. It shows something about student nurses' own health seeking behaviour. There is tremendous use of the word 'stress' which partly reflects their own feelings at that time of the year (just after their written examinations); and 
Tabie 2a: THEMES from Question 1.

\section{Question 1: "How do you know that you are sick?}

\begin{tabular}{|c|c|c|}
\hline $\begin{array}{ll}\text { * } & \text { vomiting } \\
\text { * } & \text { sleeping } \\
\text { tired/lethargic } & \text { eyes won't open } \\
* & \text { can't sleep } \\
\text { * } & \text { totally groovy } \\
\text { * } & \text { feel bad } \\
\text { - dreams of wizard \& } & \text { becomes ill } \\
\text { * person is confirmed as } \\
\text { having an evil spirit. } \\
\text { * routine affected } \\
\text { * feel cold \& shivery } \\
\text { off-balance } \\
\text { * nun down \& high } \\
\text { depressed } \\
\text { * temperamental } \\
\text { * restlessness } \\
\text { unable to digest } \\
\text { * initable } \\
\text { * not usual vibrant seff }\end{array}$ & $\begin{array}{l}\text { feels sick all the time } \\
\text { [question should be: } \\
\text { how do I know when I } \\
\text { am well?, he said] } \\
\text { * body tells me } \\
\text { - must get away from } \\
\text { noise } \\
\text { - talks to ancestor } \\
\text { - head like some-body } \\
\text { banging on a door } \\
\text { dort feel like my first } \\
\text { moming cigarelte. } \\
\text { - painaches } \\
\text { - numbness } \\
\text { - grotty } \\
\text { - cart do normal activities }\end{array}$ & 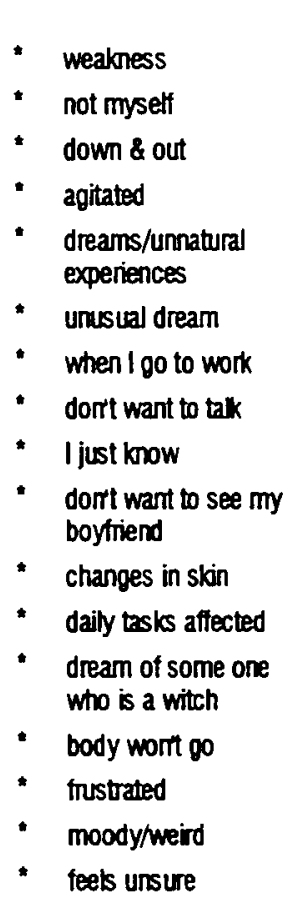 \\
\hline
\end{tabular}

Tabie 2b: THEMES from Question 2.

Question 2: What do you do when you are sicke?

\begin{tabular}{|c|c|c|}
\hline $\begin{array}{l}\text { * lie down /sleep } \\
\text { * smoke a joint } \\
\text { * ignore it } \\
\text { * depends } \\
\text { * } g 0 \text { to mother: a murse } \\
\text { - self-care } \\
\text { " } 90 \text { to chemist } \\
\text { pharmacist } \\
\text { * to doctor - only in an } \\
\text { emergency }\end{array}$ & $\begin{array}{l}\text { to dr. if a certificate is } \\
\text { reqd. } \\
\text { - mother's remedy } \\
\text { - } \text { seff-medicate } \\
\text { mope around } \\
\text { - analyze diet } \\
\text { bathe in lavendar } \\
\text { * stay at home } \\
\text { to G.P if I have } \\
\text { money/on medical aid. }\end{array}$ & $\begin{array}{l}\text { homeopath } \\
\text { * } \quad \text { to G.P. if serious } \\
\text { to traditional } \\
\text { healer/samoma } \\
\text { - herbal medicine } \\
\text { - determine what is morg } \\
\text { - take a bath } \\
\text { - take it easy } \\
\text { - take panados } \\
\text { - call house-dr. }\end{array}$ \\
\hline
\end{tabular}

Tabie 2c: THEMES from Question 3.

Question 3: What do you think causes you to be sick?

\begin{tabular}{|c|c|c|}
\hline 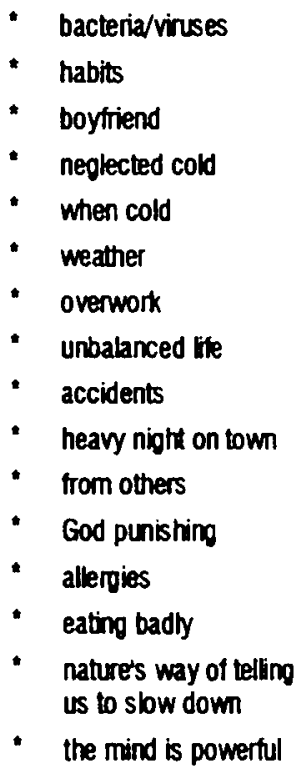 & $\begin{array}{l}\text { - } \quad \text { sturtying too late } \\
\text { bad living conditions } \\
\text { not payino enough } \\
\text { attention to body } \\
\text { messages } \\
\text { pushing body beyond } \\
\text { limis } \\
\text { poor tood (trom nursing } \\
\text { students) } \\
\text { substance abuse } \\
\text { - dress (loo little) } \\
\text { lack of ease } \\
\text { - psychological causes } \\
\text { * lack of exercise } \\
\text { - lack of vitamins } \\
\text { - jeabusy }\end{array}$ & 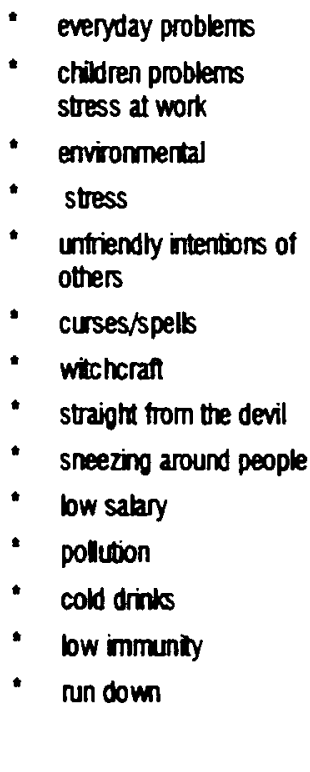 \\
\hline
\end{tabular}

partly that of others. Many interviewed their peers (there was no overlap in this: if a student had been interviewed once she was not interviewed again). Poor diet, lack of vitamins and overwork became themes amongst interviewed student nurses.

3. It gave the students a chance to be both interviewer and interviewee. I believe it gave them skill and confidence in interviewing. One must realise that these students have studied no pathophysiology.

4. Many became aware of the costs of health through their respondents' replies. The expense of going to a doctor was shown and the fact that these respondents felt that they could not afford to go unless they were really sick

5. Some became aware of the total lack of health knowledge in their interviewees and recommended that more health education be given to these people. One such respondent said, "First (the interviewee) had pain in her breast, loses weight, the pain gets worse and she becomes anxious. People advised her to buy some kind of herbs which would be good for her problem from the Rasta. She buys these herbs and wrapped her breast with these herbs as she was told. Instead of getting cured she feels some lumps from her breast which seems as if they are going to make sores. She goes to the hospital and her breast was cut off because it was damaged".

Treadwell (1992) shows that $46.7 \%$ of persons with cervical cancer visited the traditional healer, and that the medicine s/he prescribed was taken. The efficacy of the treatment was not addressed. Only 3\% of her respondents had their cancer discussed by the healer. Another nurse who came across a very uncertain diabetic recommended: "The patient needs to be educated and told in the language that he knows. The person needs to be told why various tests are done."

Although one can look at this study as an innovative method in teaching students one aspect of sociology - a method that gave the students the opportunity to become empowered and responsible for their own learning -it makes no claim to be academically erudite. It is merely a first step. To have done more, taken it further, would not show what students are capable of in their first year. 
TABLE 3: African experiences and dreams

(as told by the interviewee and written by the interviewer)

1. "A 20 year old lady from Gugulethu whom I met at Shoprite. She told me that before she gets sick she started to lose weight. lose her appetite, and that the sight and smell of food caused her to vomit. She went to the clinic for two years and they could not help her. Instead she was getting thinner and thinner. She was sleeping at midday and she dreamt of a man who was talking to her and pleading with her to accept the job they were offering her. He said ste had been appointed by her ancestors to be a healer and if she accepts she will be healed. On telling her parents this dream they encouraged her to accept so that she would be cured and they would not lose her. They had a big feast, sacrificed a goat to the ancestors, African beer was made and she was cured".

2. "When I don't sleep well and have bad dreams every night, then I go to the priest The one who uses water to heal - 'umthan-dazeli'. The illness is the evil spirits'

3a. "I do not sleep well and have bad dreams every night I go to my church prophet and he interprets my dreams. I believe that sickness is caused by the evil spirits and dernons".

3b. "When I feel something moving inside my stomach and it causes pain sometimes I go to the 'isangoma' he uses bones and throws them in front of me, they tell him what is wrong with me. I believe In what the sangoma tells me that I have got black poison ('idliso') in my stomach".

4. "I met an African lady and asked her how she knows she is sick? She said when she is not feeling well strange things happen to her like bad dreams, crying in her sleep during the night, and a tendency of not wanting to speak to people. She puts some herbs to the fire before she goes to sleep ('ukuqhumisa') so that she can get rid of bad dreams. If this does not help she consults the traditional healer ('isangoma') to diagnose her illness. He will refer her to the herbalist ('inyanga') for treatment. Evil spirits are the cause of her disease".

5. "I know I am sick by dreaming about someone that you suspect is a witch. I make African beer and ask the ancestor to protect me against the evil. It could be the ancestors causing the illness. They stop protecting me because I never made African beer. So I talk to them and ask for protection against the evil spirit and witchcraft.
1. "If she got bad luck at home or work she knows that someone is after her. If her face develops pimples, instantly she knows she is sick and she must do something. She goes to a dense forest and picks herbs, finds roots of some trees (inqwebeba). Then she does hyafutha' meaning she wraps herself with blankets, sits with the boiling water with the herbs, and her face facing the boiling herbs. Then her whole body sweats and she knows that the bad luck and pimples will disappear. She knows that it is the witches that make bad luck - the disease is 'ungqwaliso' which means bad luck'.

2. "When I feel down, frightened and sweating, always during the night. Then I go to the Sangoma who will throw bones and tell me what is going on"

3. "A 32 year old man I met in the train. He was with his wife. He said, ' First she feels dizy, after some lew seconds she falls down, after that I don't know what happens. Her body is jerking and she hears some voices although she seems to be unconscious at that time'. They go to the traditional healer as they believe that this sickness is caused by evil spirits from witches (due to these funny voices) The traditional healer gave them meicine and promised to stop these witches Irom doing this evil work".

4. "A 29 year old man who I met in the bus terminus. He said he stays in Langa. When he leels sick he just feels as if there is something moving inside his back and then his joints get weakened and he can't move. He leels lots of pains. He went to the traditional healer and even to the hospital and nothing helped him. He went to a church where priests make a big prayer for him so that God can take away these evil spirits from him, after that he gets cured and all those evil spirits were gone".

5. "A Christian gentleman said that when he is not feeling well he feels dull. When he feels pain he knows that he is sick. When he is sick he prays to God to relieve his suffering. He does not go to the doctor because his religion does not allow him to use medicine. He believes that the cause of his illness is a test from God to deter-mine how deep is his faith".Many of these dreams/experiences were reported by other interviewers (Where any student - black. white, or coloured had interviewed traditional and/or rural Africans. No dreams as such were reported by interviewers who had interviewed the other cultural groups).
5. These recorded interviews are very similar to those discussed by de Jong in his book (q.v.)

\section{References}

De Jong Joop T V M (1987) A Descent into African Psychiatry. Royal Tropical Institute, the Netheriands.

de Villiers L \& van der Wal D (1995) Putting Leininger's nursing theory and "culture care diversity and universality" into operation in the curriculum. Parts I \& II. Curationis. Vol 18, No. 1, December, 1995. pgs. 56-64.

Leininger M M (1981)Caring: an essential hwoman need. Slack Inc., Thorofare, New Jersey.
Leininger M M (ed)(1984) Care. The essence of nursing and health. Human Care \& Healith Series. Detroit: Wayne State University Press.

Leiminger M M \& Watson J (eds.)(1990) The Caring Imperitive in Education. New York: National Leagne for Nursing.

Mashaba T G, \& Brink H L (eds)(1994) Nursing Education: an international perspective. Keawyn: Juta.

Masi R, Mensah L, \& McLeod K A (eds.)(1993) Health \& cultures - exploring the relationships. Vols. I \& II. Mosaic Press, New York.

McGee P (1994) Culmally sensitive and culturally comprehensive care. British Journal of Nursing Vol 3, No 15, pgs. 789-792.
Oosthuizen Anne-Mart (1996) Dealing with Cultural Differences in Pera S A \& Van Tonder $S$ (eds.)(1996) Ethics in Nursing Practice. Kenwyn: Juta \& Co.

Spector R E (3rd ed.)(1991) Cultural Diversity in health and Illness. San Mateo: Appleton and Lange.

Treadwell Ina (1992) Discase-related needs of Black patients with cervical cancer. Curationis, Vol. 15, No. 1, 1992 pgs. 37-41.

\begin{tabular}{c} 
Sandra Haegert \\
$\begin{array}{c}\text { B.Cur (Unisa), M.A. (Ed) East Anglia } \\
\text { Lecturer: Carinus Nursing College } \\
\text { Cape Town }\end{array}$ \\
\hline
\end{tabular}

